\title{
ANALISIS PENGARUH DAYA TARIK WISATA TERHADAP KEPUTUSAN BERKUNJUNG WISATAWAN \\ (STUDI PADA WISATAWAN KEBUN BINATANG GEMBIRALOKA ZOO YOGYAKARTA)
}

\author{
Niken Retno Wardani \\ nikenrw07@gmail.com \\ Universitas Ahmad Dahlan \\ Dyah Fitriani \\ dhifa_dhe@yahoo.com \\ Universitas Ahmad Dahlan
}

\begin{abstract}
ABSTRAK
This study aims to analyze the influence of tourist attraction on tourist visiting decisions (study of zoo tourists Gembiraloka Zoo Yogyakarta), both partially and simultaneously. Population in this study are visitors who visit Gembiraloka Zoo Yogyakarta. Samples taken were 60 respondents with the sampling technique using Non Probability Sampling with Purposive Sampling. Types of data are primary data and techniques data collection using a questionnaire that has been tested first with validity and reliability tests. Data analysis method used is quantitative analysis using multiple linear regression, $t$ test, and $F$ test coefficient of determination (R2). Based on the results of data analysis with SPSS program statistical tools 20 , it can be concluded that the price variable (X1) has a significant effect on decision to visit tourists with a sign value of 0.018. Place (X2) no significant effect on the decision of visiting tourists with the sign value is 0.089 . Product (X3) has a significant effect on decisions visiting tourists with a sign value of 0.033. Employees (X4) are influential significant to tourists visiting decisions with a sign value of 0.019 . Simultaneously the price, place, product, and employee have a significant effect to the decision to visit tourists with a sign value of 0,000 Coefficient the resulting determination of 0723 which means that at $72.3 \%$ the decision to visit the Gembiraloka Zoo in Yogyakarta is influenced by all four variables are used, and the rest are influenced by other variables.
\end{abstract}

Keywords: Prices; Places; Products; Employees; Visiting Decisions.

\section{PENDAHULUAN}

Pariwisata merupakan salah satu sumber devisa bagi suatu wilayah atau negara. Dengan adanya pariwisata maka suatu negara atau lebih khususnya pemerintah daerah tempat obyek wisata itu berada, akan mendapatkan pemasukan dari pendapatan setiap obyek wisata yang ada. Pariwisata saat ini sudah menjadi industri yang mempunyai pengaruh besar dalam pembangunan ekonomi dan sosial di negara yang sedang berkembang termasuk Indonesia. Sektor pariwisata dapat memberikan kontribusi yang sangat besar bagi pertumbuhan ekonomi di kotakota tujuan wisata bahkan negara, karena dapat memberikan kesempatan kerja, peningkatan pendapatan, perubahan taraf hidup dan kesejahteraan. Indonesia merupakan salah satu negara tujuan wisata di dunia, hal ini dikarenakan selain letaknya yang strategis dan wilayahnya yang sangat luas, Indonesia memiliki daerah-daerah tujuan wisata yang mempunyai keunikan dan berbeda-beda di setiap daerahnya. Salah satu daerah wisata 
unggulan yang ada di Indonesia adalah D.I Yogyakarta.

Sebagai salah satu provinsi terbesar di Indonesia, Daerah Istimewa Yogyakarta dikenal sebagai sebutan kota perjuangan, kota wisata, pusat kebudayaan, dan pusat pendidikan. Yogyakarta memiliki kekayaan potensi pesona alam dan budaya yang masih sangat terjaga keaslian dan keindahannya. Daerah Istimewa Yogyakarta merupakan salah satu provinsi yang industri pariwisatanya tengah mengalami perkembangan. Yogyakarta terkenal sebagai provinsi destinasi pariwisata, khususnya wisata alam, wisata budaya, wisata sejarah, wisata belanja dan wisata kuliner di Pulau Jawa. Keanekaragaman upacara keagamaan dan budaya dari berbagai agama serta didukung oleh kreatifitas seni dan keramah tamahan masyarakatnya, membuat Yogyakarta pantas mendapat julukan sebagai "Daerah Istimewa Yogyakarta".

Kunjungan wisatawan ke daerah tujuan wisata biasanya dikerenakan adanya daya tarik dari tempat wisata tersebut. Dimana dengan adanya daya tarik tersebut mendorong wisatawan untuk berkunjung. Daya tarik wisata pada daerah tujuan wisata tertentu akan menjadi daya saing apabila daerah tujuan wisata tersebut lebih baik dibandingkan daerah tujuan wisata lainnya. Menurut UndangUndang Republik Indonesia Nomor 10 Tahun 2009 tentang Kepariwisataan, daya tarik wisata adalah segala sesuatu yang memiliki keunikan, keindahan, dan nilai yang berupa keanekaragaman kekayaan alam, budaya, dan hasil buatan manusia yang menjadi sasaran atau tujuan kunjungan wisatawan.

Dayak tarik dalam segi pariwisata dipengaruhi oleh beberapa faktor, salah satunya adalah bauran pemasaran jasa yang meliputi: harga (price), tempat/lokasi (place), produk (product), promosi (promotion), karyawan (people), proses (process), bukti fisik (physical evidence). Selain itu juga terdapat faktor yang berasal dari pengunjung sendiri seperti selera pengunjung, pendapatan, jarak tempuh perjalanan.

Obyek yang akan diambil dalam penelitian ini adalah Gembiraloka Zoo Yogyakarta. Gembiraloka Zoo merupakan satu-satunya destinasi wisata dengan obyek kebun binatang di Yogyakarta. Kebun Binatang dapat digolongkan dalam wisata fauna yang termasuk dalam jenis wisata alam. Gembiraloka Zoo menawarkan obyek kebun raya kebun binatang yang dapat menjadi tempat rekreasi berwawasan lingkungan yang kreatif, menarik, dan edukatif. Sehingga Gembiraloka Zoo mempunyai daya tarik tersendiri bagi para wisatawan.

Tujuan dari penelitian ini di antaranya: 1) untuk menganalisis pengaruh harga terhadap keputusan berkunjung wisatawan Gembiraloka Zoo, 2) untuk menganalisis pengaruh tempat terhadap keputusan berkunjung wisatawan Gembiraloka Zoo, 3) untuk menganalisis pengaruh produk terhadap keputusan berkunjung wisatawan Gembiraloka Zoo, 4) untuk menganalisis pengaruh karyawan terhadap keputusan berkunjung wisatawan Gembiraloka Zoo dan 5) untuk menganalisis pengaruh harga, tempat, produk, karyawan terhadap keputusan berkunjung wisatawan Gembiraloka Zoo.

\section{REVIEW LITERATUR DAN HIPOTESIS}

\section{Landasan Teori}

1. Daya Tarik Wisata

Daya tarik pengunjung atau wisatawan merupakan suatu keunikan atau ciri khas tersendiri dan keistimewaan yang dimiliki oleh suatu obyek wisata sehinggadapat menarik wisatawan untuk berkunjung ke obyek wisata tersebut.

\section{Harga}

Menurut Lupiyoadi (2013) harga adalah berbagai manfaat yang dimiliki oleh suatu produk jasa yang 
dibandingkan dengan berbagai biaya (pengorbanan) yang ditimbulkan dalam mengonsumsi jasa tersebut.

\section{Tempat / Lokasi}

Menurut Tjiptono (2011) Tempat atau lokasi adalah sebuah titik tertentu yang dipilih oleh perusahaan untuk melaksanakan segala aktivitas usahanya, dimana titik tersebut mempunyai pengaruh terhadap strategistrategi usaha dari perusahaan yang bersangkutan.

\section{Produk}

Menurut Kotler (2009) produk adalah segala sesuatu yang dapat ditawarkan ke pasar untuk mendapatkan perhatian, di beli, digunakan, atau dikonsumsi yang dapat memuaskan keinginan atau kebutuhan.

5. Karyawan

Orang yang dimaksud dalam jasa pariwisata merupakan penyedia jasa yang melayani wisatawan. Dalam hubungannya dengan pemasaran jasa penyedia jasa sangat mempengaruhi kualitas jasa yang diberikan. Karyawan disini sedikitnya memiliki tiga hal yaitu service personnel, the tourist them selves, dan local resident. Menurut Lupiyoadi (2013) keputusan dalam faktor "orang" ini berarti berhubungan dengan seleksi, pelatihan, motivasi, dan manajemen sumber daya manusia. Untuk mencapai kualitas yang terbaik, pegawai harus dilatih untuk menyadari pentingnya pekerjaan mereka, yaitu memberikan konsumen kepuasan dalam memenuhi kebutuhannya. Pentingnya SDM dalam pemasaran jasa berkaitan erat dengan pemasaran internal (internal marketing).

6. Keputusan Konsumen

$$
\text { Menurut Swastha }
$$
mengemukakan keputusan konsumen adalah motif atau dorongan yang timbul yang disebabkan oleh adanya kebutuhan dan keinginan.

\section{Penelitian Terdahulu}

Wira Setyo (2016) melakukan penelitian dengan menggunakan variabel bauran pemasaran jasa, keputusan pembelian dan kepuasan pelanggan. Hasilnya keputusan pembelian berperan dalam hubungan dengan variabel bauran pemasaran jasa dan variabel kepuasan pelanggan.

Fitria Aprillia (2015) melakukan penelitian dengan menggunakan variabel Word of Mouth, minat berkunjung dan keputusan berkunjung. Hasilnya word of mouth berpengaruh terhadap minat berkunjung, word of mouth berpengaruh terhadap keputusan berkunjung dan minat berkunjung berpengaruh terhadap keputusan berkunjung.

\section{Hipotesis}

H1: Harga berpengaruh signifikan terhadap keputusan berkunjung wisatawan.

H2: Tempat berpengaruh signifikan terhadap keputusan berkunjung wisatawan.

H3: Produk berpengaruh signifikan terhadap keputusan berkunjung wisatawan.

H4: Karyawan berpengaruh signifikan terhadap keputusan berkunjung wisatawan.

H5: Harga, Tempat, Produk, Karyawan bersama-sama berpengaruh signifikan terhadap keputusan berkunjung wisatawan.

\section{METODE PENELITIAN}

\section{Populasi dan Sampel}

Populasi merupakan keseluruhan wilayah, individu, obyek, gejala atau peristiwa untuk generalisasi suatu kesimpulan. Menurut Sugiyono (2011) 
populasi adalah wilayah generalisasi yang terdiri atas obyek/subyek yang mempunyai kualitas dan karakteristik tertentu yang ditetapkan oleh peneliti untuk dipelajari dan kemudian ditarik kesimpulannya. Populasi dalam penelitian ini adalah pengunjung yang melakukan atau pernah melakukan kunjungan ke Gembiraloka Zoo Yogyakarta.

Sampel merupakan bagian dari populasi yang ingin diteliti. Menurut Sugiyono (2011) sampel adalah bagian dari jumlah dan karakteristik yang dimiliki oleh populasi. Sehingga sampel merupakan bagian dari populasi yang ada, sehingga untuk pengambilan sampel harus menggunakan cara tertentu yang didasarkan oleh pertimbanganpertimbangan yang ada.

Jumlah sampel yang digunakan dalam penelitian ini sebanyak 60 responden, dengan mengacu pada rumus penentuan jumlah sampel menurut Sugiyono (2011), yaitu minimal $10 \mathrm{x}$ jumlah variabel. Sehingga peneliti mengambil sampel sebanyak 60 .

\section{Definisi Operasional}

1. Variabel Independen

a. Harga, yaitu jumlah uang yang dibebankan untuk sebuah produk/jasa atau jumlah nilai yang konsumen tukarkan untuk mendapatkan manfaat dari memiliki atau menggunakan produk/jasa tersebut. Indikator yang digunakan di antaranya harga tiket masuk, sistem pembayaran, harga makanan dan minuman, harga tiket wahana dan harga merchandise.

b. Tempat, yaitu sebuah titik tertentu yang dipilih oleh perusahaan untuk melaksanakan segala aktivitas usahanya, dimana titik tersebut mempunyai pengaruh terhadap strategistrategi usaha dari perusahan tersebut. Indikator yang digunakan di antaranya lokasi obyek, kemudahan akses ke lokasi, kejelasan rute mengelilingi obyek, kenyamanan tempat dan kebersihan lingkungan obyek.

c. Produk, yaitu segala sesuatu yang dapat ditawarkan ke pasar untuk mendapatkan perhatian, dibeli, atau dikonsumsi yang dapat memuaskan keinginan atau kebutuhan. Indikator yang digunakan di antaranya kelengkapan jenis satwa, atraksi dan wahana.

d. Karyawan, yaitu semua pelaku yang berperan dalam pemberian pelayanan sehingga dapat mempengaruhi persepsi pembeli. Indikator yang digunakan di antaranya sikap dan perilaku petugas, daya tanggap petugas, pelayanan petugas dan penampilan petugas.

\section{Variabel Dependen}

Variabel dependen (Y) yang digunakan dalam penelitian ini adalah keputusan berkunjung. Keputusan berkunjung adalah proses dimana seorang pengunjung melakukan penilaian dan memilih satu alternatif yang diperlukan berdasarkan pertimbangan tertentu. Indikator yang digunakan di antaranya keputusan pemilihan tempat wisata, keputusan waktu berkunjung dan keputusan pemilihan jenis wisata.

\section{Uji Instrumen}

\section{Uji Validitas}

Uji validitas menurut Ghozali (2013) digunakan untuk mengukur sah atau valid tidaknya suatu kuesioner. Suatu kuesioner dikatakan valid jika pertanyaan atau pernyataan pada kuesioner mampu untuk mengungkapkan sesuatu yang akan diukur oleh kuesioner tersebut. Jadi, validitas adalah mengukur apakah pertanyaan atau pernyataan dalan 
kuesioner yang sudah dibuat betul-betul dapat mengukur apa yang hendak diukur. Untuk menguji validitas dalam penelitian ini adalah construct validity dengan menggunakan metode Confirmatory Factor Analysis (CFA). Semua item pertanyaan atau pernyataan dinyatakan valid jika nilai faktor loading $>0,5$.

\section{Uji Reliabilitas}

Reliabilitas menurut Ghozali (2013) adalah alat ukur untuk mengukur suatu kuesioner yang merupakan indikator dari suatu variabel atau konstruk. Suatu kuesinoner dapat dikatakan reliabel atau handal jika jawaban seseorang terhadap pertanyaan atau penyataan adalah konsisten atau stabil dari waktu ke waktu. Jawaban responden terhadap pertanyaan atau pernyataan dikatakan reliabel jika masing-masing pertanyaan atau pernyataan dijawab secara konsisten atau jawaban tidak boleh acak oleh karena itu masing-masing pertanyaan atau pernyataan hendak mengukur hal yang sama.

Menurut Ghozali (2013) jika jawaban terhadap indikator ini acak, maka dapat dikatakan tidak reliabel.Uji reliabilitas dalam penelitian ini adalah dengan membandingkan Cronbach Coefficient Alpha (r Alpha) pada hasil olahan SPSS 20 dengan Rule of Thumb. Menurut Ghozali (2013) suatu variabel dapat dikatakan reliabel jika nilai cronbach alpha $>0,60$.

\section{Teknik Analisis Data}

1. Analisis Regresi Berganda

$\mathrm{Y}=\mathrm{a}+\mathrm{b} 1 \mathrm{X} 1+\mathrm{b} 2 \mathrm{X} 2+\mathrm{b} 3 \mathrm{X} 3+\mathrm{b} 4 \mathrm{X} 4$

Dimana :

$\mathrm{Y}=$ Keputusan Berkunjung

$\mathrm{a}=$ Konstanta

$\mathrm{b}=$ Koefisien regresi

$\mathrm{X} 1=$ Harga

$\mathrm{X} 2$ = Tempat

$\mathrm{X} 3$ = Produk

$\mathrm{X} 4$ = Karyawan

\section{Uji Hipotesis}

\section{Uji Parsial (Uji T)}

Uji t digunakan untuk mengetahui pengaruh masing-masing variabel bebas secara parsial terhadap variabel terikat. Untuk mengetahui apakah ada pengaruh secara parsial variabel bebas terhadap variabel terikat. Dapat juga dikatakan Ho diterima jika $\mathrm{t}$ hitung $<\mathrm{t}$ tabel dengan $\alpha=5 \%$ dan signifikansi t hitung lebih besar dari 0,05 dan Ha diterima jika t hitung $>\mathrm{t}$ tabel dengan $\alpha=5 \%$ dan signifikansi t hitung lebih kecil dari 0,05 .

\section{Uji Simultan (Uji F)}

Uji $F$ atau pengujian model digunakan untuk mengetahui pengaruh secara simultan antara variabel bebas terhadap variabel terikat. Untuk mengetahui apakah model regresi linier berganda yang digunakan sesuai atau tidak. Ho diterima jika $\mathrm{F}$ hitung < $\mathrm{F}$ tabel dengan $\alpha=5 \%$ dan signifikansi $\mathrm{F}$ hitung lebih besar dari 0,05 dan $\mathrm{Ha}$ diterima jika $\mathrm{F}$ hitung $>\mathrm{F}$ tabel dengan $\alpha=5 \%$ dan signifikansi $F$ hitung lebih kecil dari 0,05 .

\section{Uji Koefisien Determinasi}

Koefisien determinasi

(R2) menurut Ghozali (2013) dimaksudkan untuk mengukur seberapa jauh kemampuan model dalam menerangkan variasi terkait. Tingkat ketepatan paling baik dalam analisa regresi dimana hal yang ditunjukan oleh besarnya koefisien determinasi (R2) antara 0 (nol) dan 1 (satu). Koefisien determinasi (R2) nol variabel independen sama sekali tidak berpengaruh terhadap variabel dependen. Apabila koefisien determinasi semakin mendekati satu, maka dapat dikatakan bahwa variabel independen berpengaruh terhadap variabel dependen. Selain itu koefisien determinasi (R2) dipergunakan untuk mengetahui prosentase perubahan 
variabel tidak bebas (Y) yang disebabkan oleh variabel bebas (X).

\section{HASIL PENELITIAN DAN PEMBAHASAN}

\section{Hasil Analisis Responden}

Karakteristik responden berdasarkan asal

\begin{tabular}{|c|c|c|}
\hline Asal & Frekuensi & Prosentase \\
\hline DIY & 33 & $55 \%$ \\
\hline Jawa Tengah & 10 & $16,66 \%$ \\
\hline Jawa Barat & 2 & $3,33 \%$ \\
\hline DKI Jakarta & 1 & $1,66 \%$ \\
\hline Aceh & 1 & $1,66 \%$ \\
\hline Riau & 3 & $5 \%$ \\
\hline Jambi & 1 & $1,66 \%$ \\
\hline Bengkulu & 1 & $1,66 \%$ \\
\hline Sumatra Selatan & 2 & $3,33 \%$ \\
\hline Sumatra Utara & 1 & $1,66 \%$ \\
\hline Bali & 1 & $1,66 \%$ \\
\hline NTB & 1 & $1,66 \%$ \\
\hline Kalimantan Barat & 1 & $1,66 \%$ \\
\hline Sulawesi Utara & 1 & $1,66 \%$ \\
\hline Maluku Utara & 1 & $1,66 \%$ \\
\hline Jumlah Responden & 60 & $100 \%$ \\
\hline
\end{tabular}

Berdasarkan data di atas, maka diperoleh data karakteristik responden berdasarkan asal daerahnya sebagai berikut:

1. Responden yang berasal dari Daerah Istimewa Yogyakarta berjumlah 33 orang atau sebesar $55 \%$ dari total 60 responden.

2. Responden yang berasal dari Jawa Tengah berjumlah 10 orang atau sebesar 16,66 \% dari total 60 responden.

3. Responden yang berasal dari Jawa Barat berjumlah 2 orang atau sebesar 3,33\% dari total 60 responden.

4. Responden yang berasal dari DKI Jakarta berjumlah 1 orang atau sebesar $1,66 \%$ dari total 60 responden.

5. Responden yang berasal dari Aceh berjumlah 1 orang atau sebesar 1,66\% dari total 60 responden.

6. Responden yang berasal dari Riau berjumlah 3 orang atau sebesar $5 \%$ dari total 60 responden.

7. Responden yang berasal dari Jambi berjumlah 1 orang atau sebesar 1,66\% dari total 60 responden.
8. Responden yang berasal dari Bengkulu berjumlah 1 orang atau sebesar 1,66\% dari total 60 responden.

9. Responden yang berasal dari Sumatra Selatan berjumlah 2 orang atau sebesar 3,33\% dari total 60 responden.

10. Responden yang berasal dari Sumatra Utara berjumlah 1 orang atau sebesar $1,66 \%$ dari total 60 responden.

11. Responden yang berasal dari Bali berjumlah 1 orang atau sebesar 1,66\% dari total 60 responden.

12. Responden yang berasal dari NTB berjumlah 1 orang atau sebesar 1,66\% dari total 60 responden.

13. Responden yang berasal dari Kalimantan Barat berjumlah 1 orang atau sebesar $1,66 \%$ dari total 60 responden.

14. Responden yang berasal dari Sulawesi Utara berjumlah 1 orang atau sebesar 1,66\% dari total 60 responden.

15. Responden yang berasal dari Maluku Utara berjumlah 1 orang atau sebesar $1,66 \%$ dari total 60 responden.

Karakteristik responden berdasarkan umur

\begin{tabular}{|c|c|c|}
\hline Umur & Frekuensi & Prosentase \\
\hline $17-20$ Tahun & 17 & $28,3 \%$ \\
\hline $21-30$ Tahun & 33 & $55 \%$ \\
\hline $31-40$ Tahun & 7 & $11,6 \%$ \\
\hline$>40$ Tahun & 3 & $5 \%$ \\
\hline Jumlah Responden & 60 & $100 \%$ \\
\hline
\end{tabular}

Berdasarkan data di atas, maka diperoleh data karakteristik responden berdasarkan umur sebagai berikut:

1. Responden yang berumur 17-20 tahun berjumlah 17 orang atau sebesar 28,3 $\%$ dari total 60 responden.

2. Responden yang berumur 21-30 tahun berjumlah 33 orang atau sebesar $55 \%$ dari total 60 responden.

3. Responden yang berumur 31-40 tahun berjumlah 7 orang atau sebesar 11,6\% dari total 60 responden. 
4. Responden yang berumur lebih dari 40 tahun berjumlah 3 orang atau sebesar $5 \%$ dari total 60 responden.

Karakteristik responden berdasarkan jenis kelamin

\begin{tabular}{|c|c|c|}
\hline Jenis Kelamin & Frekuensi & Prosentase \\
\hline Laki-Laki & 25 & $41,6 \%$ \\
\hline Perempuan & 35 & $58,3 \%$ \\
\hline Jumlah responden & 60 & $100 \%$ \\
\hline
\end{tabular}

1. Responden yang berjenis kelamin laki-laki berjumlah 25 orang atau sebesar 41,6\% dari total 60 responden.

2. Responden yang berjenis kelamin perempuan berjumlah 35 orang atau $58,3 \%$ dari total 60 responden.

\section{Hasil Penelitian}

1. Hasil Uji Validitas

Hasil Uji Validitas

\begin{tabular}{|c|c|c|c|c|c|c|c|}
\hline \multirow{2}{*}{ Indikator } & \multirow{2}{*}{ Pemyataan } & \multicolumn{5}{|c|}{ Komponen factor } & \multirow{2}{*}{ Status } \\
\hline & & 1 & 2 & 3 & 4 & 5 & \\
\hline \multirow{4}{*}{$\begin{array}{l}\text { Harga } \\
\text { (XI) }\end{array}$} & XI.I & 0,820 & & & & & Valid \\
\hline & $\mathrm{XI} .2$ & 0,705 & & & & & Valid \\
\hline & $\mathrm{XI}, 3$ & 0,637 & & & & & Valid \\
\hline & $\mathrm{X1.5}$ & 0,791 & & & & & Valid \\
\hline \multirow{3}{*}{$\begin{array}{l}\text { Tempat } \\
\text { (X2) }\end{array}$} & $X 2.3$ & & 0,839 & & & & Valid \\
\hline & X2.4 & & 0,751 & & & & Valid \\
\hline & X2.5 & & 0,815 & & & & Valid \\
\hline \multirow{4}{*}{$\begin{array}{l}\text { Produk } \\
\text { (X3) }\end{array}$} & X3.1 & & & 0,775 & & & Valid \\
\hline & $\begin{array}{l}X 3.3 \\
\end{array}$ & & & 0,796 & & & Valid \\
\hline & $\begin{array}{l}3.4 \\
\end{array}$ & & & 0,776 & & & Valid \\
\hline & X3.5 & & & 0,762 & & & Valid \\
\hline \multirow{5}{*}{$\begin{array}{l}\text { Karyawan } \\
\text { (X4) }\end{array}$} & $\begin{array}{l}X 4.1 \\
\end{array}$ & & & & 0,709 & & Valid \\
\hline & X4.2 & & & & 0,744 & & Valid \\
\hline & $X 4.3$ & & & & 0,534 & & Valid \\
\hline & $\begin{array}{l}X 4.4 \\
\end{array}$ & & & & 0,734 & & Valid \\
\hline & $X 4.5$ & & & & 0,752 & & Valid \\
\hline \multirow{4}{*}{$\begin{array}{l}\text { Keputusan } \\
\text { Berkunjung } \\
\text { (Y) }\end{array}$} & $\mathrm{Yl}$ & & & & & 0,788 & Valid \\
\hline & $\mathrm{Y} 2$ & & & & & 0,788 & Valid \\
\hline & Y4 & & & & & 0,700 & Valid \\
\hline & Y5 & & & & & 0,713 & Valid \\
\hline
\end{tabular}

a. Uji Validitas Variabel Harga (X1)

Tabel component matrix pada hasil output SPSS 20 sudah terbentuk 1 component, yang mempunyai 5 item pernyataan dengan indikator X1.1, X1.2, X1.3, $\mathrm{X} 1.4, \quad \mathrm{X} 1.5$, tetapi item X1.4 nilainya kurang dari 0,5 , sehingga item X1.4 dihilangkan, dan tersisa
4 item pernyataan, dengan indikator $\mathrm{X} 1.1, \mathrm{X} 1.2, \mathrm{X} 1.3, \mathrm{X} 1.5$ dimana ke empat item tersebut dapat dinyatakan valid dan dapat menjelaskan faktor varibel harga.

b. Uji Validitas Variabel Tempat (X2)

Tabel component matrix pada hasil data output SPSS 20 terbentuk 2 component, dengan indikator $\mathrm{X} 2.1, \quad \mathrm{X} 2.2, \quad \mathrm{X} 2.3, \quad \mathrm{X} 2.4, \quad \mathrm{X} 2.5$ yang mempunyai 5 item pernyataan, dimana item X2.1 dan X2.2 nilainya kurang dari 0,5 maka item X2.1 dann X2.2 dihilangkan, sehingga terbentuk 1 component, dan tersisa 3 item pernyataan. Jadi X2.3, X2.4 X2.5 dapat dinyatakan valid dan dapat menjelaskan faktor variabel tempat.

c. Uji Validitas Variabel Produk (X3)

Tabel component matrix pada hasil data output SPSS 20 terbentuk 2 component, dengan indikator $\mathrm{X} 3.1, \quad \mathrm{X} 3.2, \quad \mathrm{X} 3.3, \quad \mathrm{X} 3.4, \quad \mathrm{X} 3.5$ yang mempunyai 5 item pernyataan, dimana X3.2 nilainya kurang dari 0,5 maka item X3.2 dihilangkan, sehingga terbentuk 1 component, dan tersisa 4 item pernyataan. Jadi $\mathrm{X} 3.1, \quad \mathrm{X} 3.3, \quad \mathrm{X} 3.4, \quad \mathrm{X} 3.5$ dapat dinyatakan valid dan dapat menjelaskan faktor variabel produk.

d. Uji Validitas Variabel Karyawan (X4)

Tabel component matrix pada hasil data output SPSS 20 terbentuk 1 component, dengan indikator $\mathrm{X} 4.1, \quad \mathrm{X} 4.2, \quad \mathrm{X} 4.3, \quad \mathrm{X} 4.4, \quad \mathrm{X} 4.5$ yang mempunyai 5 item pernyataan, dimana seluruh item pernyataan tersebut dapat dinyatakan valid dan dapat menjelaskan faktor variabel karyawan.

e. Uji Validitas Keputusan Berkunjung (Y)

Tabel component matrix pada hasil data output SPSS 20 terbentuk 3 component, dengan indikator $\mathrm{Y} 1$, Y2, Y3, Y4, Y5, Y6, Y7, Y8 yang mempunyai 8 item pernyataan, 
dimana Y3, Y6, Y7, dan Y8 nilainya kurang dari 0,5 , maka item Y3, Y6, Y7, dan Y8 dihilangkan, sehingga terbentuk 1 component, dan tersisa 4 item pernyataan. Jadi Y1, Y2, Y4, Y5 dapat dinyatakan valid dan dapat menjelaskan faktor variabel keputusan berkunjung.

2. Hasil Uji Reliabilitas

Hasil Uji Reliabilitas

\begin{tabular}{|l|c|c|}
\hline \multicolumn{1}{|c|}{ Variabel } & Cronbach Alpha & Keterangan \\
\hline Harga & 0,749 & Reliabel \\
\hline Tempat & 0,748 & Reliabel \\
\hline Produk & 0,758 & Reliabel \\
\hline Karyawan & 0,717 & Reliabel \\
\hline $\begin{array}{l}\text { Keputusan } \\
\text { Berkunjung }\end{array}$ & 0,719 & Reliabel \\
\hline
\end{tabular}

Dari tabel di atas menunjukkan bahwa item pernyataan dari variabel penelitian berstatus reliabel. Hal ini terlihat dari koefisien Cronbach alpha bernilai lebih besar dari 0,60 maka instrumen penelitian (kuesioner) yang digunakan dalam penelitian dinyatakan reliabel. Dengan demikian instrumen penelitian tersebut dapat digunakan untuk meneliti data-data yang sama pada kondisi yang relatif sama juga, dengan probabilitas hasil penelitian yang dapat dipercaya.

3. Hasil Uji Regresi Linier Berganda Hasil Pengolahan Data Analisis Regresi Berganda

\begin{tabular}{|c|c|}
\hline Model & B \\
\hline (Constant) & 1,014 \\
\hline Harga & 0,167 \\
\hline Tempat & 0,163 \\
\hline Produk & 0,202 \\
\hline Karyawan & 0,260 \\
\hline
\end{tabular}

$\mathrm{Y}=1,014+0,167 \mathrm{X} 1+0,163 \mathrm{X} 2+$ $0,202 X 3+0,260 X 4$

Dari persamaan garis linier regresi berganda di atas, dapat diartikan bahwa :
$\mathrm{Y}=$ variabel yang nilainya akan diprediksi oleh variabel independen. Dalam penelitian ini yang menjadi variabel dependen adalah keputusan berkunjung wisatawan Gembiraloka Zoo, yang nilainya diprediksi oleh variabel harga, tempat, produk dan karyawan.

$\mathrm{a}=1,014$ merupakan nilai konstanta, dengan demikian nilai konstanta ini menunjukkan besarnya nilai variabel keputusan berkunjung wisatawan Gembiraloka Zoo Yogyakarta jika variabel independen sama dengan nol.

$\mathrm{b} 1=0,167$ merupakan koefisien variabel harga (X1) yang mempengaruhi keputusan berkunjung wisatawan Gembiraloka Zoo Yogyakarta (Y). Koefisien regresi (b1) sebesar 0,167 dengan tanda positif. Berdasarkan hasil tersebut, maka dapat disimpulkan bahwa apabila harga (X1) berubah atau naik satu-satuan maka keputusan berkunjung wisatawan Gembiraloka Zoo Yogyakarta akan naik sebesar 0,167 dengan asumsi variabel independen lainnya mempunyai nilai sama dengan nol. Berdasarkan hasil tersebut maka dapat disimpulkan apabila perusahaan lebih mempertimbangkan mengenai harga yang terjangkau, maka keputusan berkunjung wisatawan Gembiraloka Zoo akan mengalami peningkatan.

$\mathrm{b} 2=0,163$ merupakan koefisien variabel tempat/ lokasi (X2) yang mempengaruhi keputusan berkunung wisatawan Gembiraloka Zoo Yogyakarta (Y). Koefisien regresi (b2) sebesar 0.163 dengan tanda positif. Berdasarkan hasil tersebut, maka dapat disimpulkan bahwa apabila tempat/lokasi (X2) berubah atau naik satu-satuan, maka keputusan berkunjung wisatawan Gembiraloka Zoo Yogyakarta akan naik sebesar 0.163 dengan asumsi variabel independen lainnya mempunyai nilai sama dengan nol. Berdasarkan hasil tersebut maka dapat disimpulkan 
apabila perusahaan mempertahankan tempat/lokasi yang stategis, maka keputusan berkunjung wisatawan Gembiraloka Zoo menjadi sebuah pilihan.

b3 $=0.202$ merupakan koefisien variabel produk (X3) yang mempengaruhi

keputusan berkunjung wisatawan Gembiraloka Zoo Yogyakarta (Y).

koefisien regresi (b3) sebesar 0.202 dengan tanda positif. Berdasarkan

hasil tersebut, maka dapat disimpulkan bahwa apabila produk (X3)

berubah atau naik satu-satuan, maka keputusan berkunjung wisatawan

Gembiraloka Zoo Yogyakarta akan naik sebesar 0.202 dengan asumsi 47

variabel independen lainnya mempunyai nilai sama dengan nol.

Berdasarkan hasil tersebut maka dapat disimpulkan bahwa apabila perusahaan lebih meningkatkan produk yang lengkap maka keputusan berkunjung wisatawan Gembiraloka Zoo akan mengalami peningkatan. $\mathrm{b} 4=0.260$ merupakan koefisien variabel Karyawan (X4) yang mempengaruhi

keputusan berkunjung wisatawan Gembiraloka Zoo Yogyakarta (Y).

koefisien regresi (b4) sebesar 0.260 dengan tanda positif. Berdasarkan hasil tersebut maka dapat disimpulkan bahwa apabila karyawan (X4)

berubah atau naik satu-satuan maka keputusan berkunjung wisatawan Gembiraloka Zoo Yogyakarta akan naik sebesar 0.260 dengan asumsi variabel independen lainnya mempunyai nilai sama dengan nol.

Berdasarkan hasil tersebut maka dapat disimpulkan bahwa apabila perusahaan lebih meningkatkan kualitas karyawannya maka keputusan berkunjung wisatawan Gembiraloka Zoo akan meningkat.

4. Hasil Uji Parsial (Uji T)

Hasil Pengujian data Uji t

\begin{tabular}{|c|c|c|}
\hline Model & Sig. & Keterangan \\
\hline Harga $\left(\mathrm{X}_{1}\right)$ & .018 & Berpengaruh signifikan \\
\hline Tempat $\left(\mathrm{X}_{2}\right)$ & .089 & $\begin{array}{c}\text { Tidak berpengaruh } \\
\text { signifikan }\end{array}$ \\
\hline Produk $\left(\mathrm{X}_{3}\right)$ & .033 & Berpengaruh signifikan \\
\hline Karyawan $\left(\mathrm{X}_{4}\right)$ & .019 & Berpengaruh signifikan \\
\hline
\end{tabular}

a. Untuk variabel harga (X1), dari hasil olah data menggunakan SPSS 20 nilai sign $<$ alpha $(0,018<0,05)$, sehingga harga (X1) berpengaruh signifikan terhadap keputusan berkunjung (Y). Maka dapat disimpulan $\mathrm{H} 01$ ditolak dan Ha1 diterima yaitu ada pengaruh positif harga terhadap keputusan berkunjung wisatawan Gembiraloka Zoo Yogyakarta.

b. Untuk variabel tempat (X2), dari hasil olah data menggunakan SPSS 20 nilai sign $>$ alpha $(0,089>0,05)$, sehingga tempat (X2) tidak berpengaruh signifikan terhadap keputusan berkunjung (Y). Maka dapat disimpulan $\mathrm{H} 02$ diterima dan $\mathrm{Ha} 2$ ditolak yaitu tidak ada pengaruh positif tempat terhadap keputusan berkunjung wisatawan Gembiraloka Zoo Yogyakarta.

c. Untuk variabel produk (X3), dari hasil olah data menggunakan SPSS 20 nilai sign < alpha $(0,033<$ $0,05)$, sehingga produk (X3) berpengaruh signifikan terhadap keputusan berkunjung (Y). Maka dapat disimpulan $\mathrm{H} 03$ ditolak dan Ha3 diterima yaitu ada pengaruh positif produk terhadap keputusan berkunjung wisatawan Gembiraloka Zoo Yogyakarta.

d. Untuk variabel karyawan (X4), dari hasil olah data menggunakan SPSS 20 nilai sign $<$ alpha $(0,019<0,05)$, sehingga karyawan (X4) berpengaruh signifikan terhadap 
keputusan berkunjung (Y). Maka dapat disimpulan $\mathrm{H} 03$ ditolak dan Ha3 diterima yaitu ada pengaruh positif karyawan terhadap keputusan berkunjung wisatawan Gembiraloka Zoo Yogyakarta.

\section{Hasil Uji Simultan (Uji F)}

Hasil olah data Uji F

\begin{tabular}{|ll|c|}
\hline Model & & Sig. \\
\hline 1 & Regression & \\
& Residual & \\
& Total & \\
& & \\
& & \\
\hline
\end{tabular}

Berdasarkan dari hasil olah data dengan menggunakan SPSS 20, nilai sign < alpha $(0,000<0,05)$, sehingga $\mathrm{Ha}$ diterima dan H0 ditolak. Dengan demikian dapat disimpulkan bahwa ada pengaruh harga, tempat, produk, dan karyawan terhadap keputusan berkunjung wisatawan Gembiraloka Zoo Yogyakarta.

\section{Hasil Uji Koefisien Determinasi}

Hasil Perhitungan Koefisien Determinasi

\begin{tabular}{|l|r|}
\hline Model & R square \\
\hline 1 & .723 \\
\hline
\end{tabular}

Berdasarkan dari hasil olah data dengan menggunakan SPSS 20 diperoleh nilai koefisien determinasi R2 sebesar 0,723 hal ini menunjukkan bahwa sebesar $72,3 \%$ keputusan berkunjung wisatawan Gembiraloka Zoo Yogyakarta dipengaruhi oleh variasi keempat variabel yang digunakan yaitu harga, tempat, produk dan karyawan. Sedangkan sisanya 27,7 $\%$ dipengaruhi oleh variabel lainnya.

\section{Pembahasan}

Berdasarkan dari hasil uji t, dari keempat yang mempengaruhi keputusan berkunjung yaitu harga, tempat, produk, dan karyawan sebagai berikut:
1. Pengaruh variabel harga terhadap keputusan berkunjung wisatawan Gembiraloka Zoo Yogyakarta signifikan. Hal ini dikarenakan nilai sign $<$ alpha $(0,018<0,05)$, sehingga harga (X1) berpengaruh posisitf terhadap keputusan berkunjung (Y). Maka dapat diambil kesimpulan $\mathrm{H} 01$ ditolak dan Hal diterima yaitu ada pengaruh positif harga terhadap keputusan berkunjung wisatawan Gembiraloka Zoo Yogyakarta. Dengan demikian harga mempengaruhi wisatawan untuk melakukan kunjungan ke Gembiraloka Zoo Yogyakarta.

2. Pengaruh variabel tempat terhadap keputusan berkunjung wisatawan Gembiraloka Zoo Yogyakarta tidak signifikan. Hal ini dikarenakan nilai sign > alpha $(0,089>0,05)$, sehingga tempat (X2) tidak berpengaruh positif terhadap keputusan berkunjung (Y). Maka dapat diambil kesimpulan $\mathrm{H} 02$ diterima dan $\mathrm{Ha} 2$ ditolak yaitu tidak ada pengaruh positif tempat terhadap keputusan berkunjung wisatawan Gembiraloka Zoo Yogyakarta. Dengan demikian jauh dekatnya tempat atau lokasi wisata tidak mempengaruhi keputusan wisatawan untuk berkunjung ke Gembiraloka Zoo Yogyakarta.

3. Pengaruh variabel produk terhadap keputusan berkunjung wisatawan Gembiraloka Zoo Yogyakarta signifikan. Hal ini dikarenakan nilai sign $<$ alpha $(0,033<0,05)$, sehingga produk (X3) berpengaruh positif terhadap keputusan berkunjung (Y). maka dapat diambil kesimpulan $\mathrm{H} 03$ ditolak dan $\mathrm{Ha} 3$ diterima yaitu ada pengaruh positif produk terhadap keputusan berkunjung wisatawan Gembiraloka Zoo Yogyakarta. Dengan demikian produk mempengaruhi keputusan wisatawan untuk berkunjung ke Gembiraloka Zoo Yogyakarta. 
4. Pengaruh variabel karyawan terhadap keputusan berkunjung wisatawan Gembiraloka Zoo Yogyakarta signifikan. Hal ini dikarenakan nilai sign $<$ alpha $(0,019<0,05)$, sehingga karyawan (X4) berpengaruh positif terhadap keputusan berkunjung (Y). maka dapat diambil kesimpulan $\mathrm{H} 04$ ditolak dan Ha4 diterima, yaitu ada pengaruh positif karyawan terhadap keputusan berkunjung wisatawan Gembiraloka Zoo Yogyakarta. Dengan demikian karyawan mempengaruhi keputusan wisatawan untuk berkunjung ke Gembiraloka Zoo Yogyakarta.

Hasil uji $F$ empat variabel independen berpengaruh signifikan terhadap variabel dependen. Hal ini dikarenakan nilai sign < alpha $(0,000<$ 0,05), sehingga $\mathrm{Ha}$ diterima dan $\mathrm{H} 0$ ditolak. Dengan demikian dapat ditarik kesimpulan bahwa ada pengaruh positif harga, tempat, produk dan karyawan terhadap keputusan berkunjung wisatawan Gembiraloka Zoo Yogyakarta.

\section{KESIMPULAN DAN SARAN}

\section{Kesimpulan}

1. Terdapat pengaruh dari segi harga terhadap keputusan berkunjung wisatawan Gembiraloka Zoo Yogyakarta.

2. Tidak ada pengaruh dari segi tempat terhadap keputusan berkunjung wisatawan Gembiraloka Zoo Yogyakarta.

3. Terdapat pengaruh dari segi produk yang ditawarkan di dalam obyek terhadap keputusan berkunjung wisatawan Gembiraloka Zoo Yogyakarta.

4. Terdapat pengaruh dari segi pelayanan oleh karyawan terhadap keputusan berkunjung wisatawan Gembiraloka Zoo Yogyakarta.

5. Terdapat pengaruh dari segi harga, tempat, produk, dan karyawan terhadap keputusan berkunjung wisatawan Gembiraloka Zoo Yogyakarta.

\section{DAFTAR PUSTAKA}

Ghozali, Imam. (2013). Aplikasi Analisis Multivariate dengan Program SPSS. Yogyakarta: Badan Penerbit BPFE.

Kotler, Philip. (2009). Manajemen Pemasaran. Jakarta: Erlangga.

Lupiyoadi, Rambat. (2013). Manajemen Pemasaran Jasa. Edisi 3. Jakarta: Salemba Empat.

Sugiyono. (2011). Metode Penelitian Kuantitatif, kualitatif dan $R \& D$. Bandung: Alfabeta.

Swastha, D H. dan Irawan. (2008). Manajemen Pemasaran Modern. Edisi Kedua. Yogyakarta: Liberty Offset.

Tjiptono. (2011). Pemasaran Jasa. Malang: Bayumedia. 